TECHNICAL TRANSACTIONS 5/2017

CZASOPISMO TECHNICZNE 5/2017

MECHANICS

DOI: $10.4467 / 2353737$ XCT.17.081.6438

\author{
Monika Pawlita-Posmyk \\ Małgorzata Wzorek (m.wzorek@po.opole.pl) \\ Department of Process Engineering, Faculty of Mechanical Engineering, Technical \\ University of Opole
}

\title{
DOMESTIC SEWAGE TREATMENT PLANT OR ECOLOGICAL SEPTIC TANK
}

PRZYDOMOWA OCZYSZCZALNIA ŚCIEKÓW CZY SZAMBO EKOLOGICZNE

\begin{abstract}
In areas with scattered buildings and a low population density, the sewage management infrastructure is underdeveloped. Until recently, the only practical solution was to make a non-effluent and tight tank: a septic tank, which was one of the means to carry sewage away from detached houses in areas without sewage systems. Currently, domestic sewage treatment plants are highly popular. The paper shows the operating principle of a septic tank and a domestic treatment plant and analyses their advantages and disadvantages. Particular attention was paid to the economical aspect.
\end{abstract}

Keywords: domestic sewage treatment plant, septic tanks, cost analysis

\section{Streszczenie}

Na terenach o rozproszonej zabudowie i niewielkiej gęstości zaludnienia istnieje niedostatecznie rozwinięta infrastruktura kanalizacyjna. Do niedawna jedynym praktycznym rozwiązaniem była budowa szamba; obecnie dużą popularnością cieszą się przydomowe oczyszczalnie ścieków. W artykule porównano zasady działania i eksploatacji zbiornika bezodplywowego i oczyszczalni przydomowej. Szczególną uwagę zwrócono na aspekt ekonomiczny.

Słowa kluczowe: przydomowa oczyszczalnia ścieków, zbiorniki bezodpływowe, analiza kosztów 


\section{Introduction}

The sewage management infrastructure in rural areas is underdeveloped. Until recently, the only practical solution for areas without sewage systems was to build a non-effluent tank (a septic tank). Currently, modern domestic sewage drainage systems (domestic sewage treatment plants) are highly popular.

From the point of view of the area covered, the sewage system may be individual, home and collective. If buildings in a given area are highly scattered, the individual sewage system is used most of the time, which is the case in many villages in Poland. It is recommended for the sewage drainage systems in several households to be joined into one system with an inseparable sewer network [1]. Local sewage management devices are used when the construction of sewage systems and a collective sewage treatment plant is not possible due to economic reasons [2]. This is most often the case with areas where buildings are scattered, i.e. in the countryside or on the outskirts of towns [3].

The following solutions may be used in such areas:

- domestic sewage treatment plants, which are designed for detached house, several buildings in proximity (the so-called small centralisation) or several public facilities,

- non-effluent tanks (septic tanks) serving to periodically accumulate sewage, which is then transported to the closest sewage treatment plant.

The best solution may be selected on the basis of analyses of local and technical and economic conditions (e.g. construction costs, investment outlay and operating costs) [2].

\subsection{Domestic sewage treatment plant}

Domestic sewage treatment plants are becoming ever more popular every year [2]. The plants do not pose any threat to ground and surface waters if the quality of treated sewage carried away from the plant meets the current standards [4]. Treated sewage may be drained into the ground by means of e.g. a drain well found in the user's estate or a water system found outside the lot [5].

The output data for design of selection of domestic sewage treatment plants is illustrated in Fig. 1 [2].

There are many types of domestic sewage treatment plants available on the market, i.e. drainage, biological or plant-based treatment plants and ones preceded by mechanical separation of impurities. Fig. 2 and 3 show five most often used technological solutions concerning domestic sewage treatment plants. The choice of a specific type of domestic sewage treatment plants is dictated by many factors, e.g. technical and economic conditions. Drainage treatment plants rank among the least complex domestic treatment plants (Fig. 2a). An additional merit of this solution is the low cost of devices, no supervision and no need to possess specialist knowledge (the plants operate virtually unattended).

Treatment plants with subsurface leaching system are most frequently used in permeable soils, where sewage is initially treated in a settling tank and distributed into drainage pipes, from where it disperses into the ground. Treatment plants with a sand filter (Fig. 2b) are used mainly where the permeability of soil is too high or too low [5]. 
Unit the amount of sewage:

$\mathrm{q}_{\mathrm{d} \text { medium }}=150 \mathrm{dm}^{3} /($ resident $\cdot$ day $)$

$\mathrm{q}_{\mathrm{d} \text { maximum }}=195 \mathrm{dm}^{3} /($ resident $\cdot$ day $)$

$\mathrm{q}_{\mathrm{h} \text { maximum }}=14,4 \mathrm{dm}^{3} /($ resident $\cdot$ hour $)$
Individual pollutant loads:

$\mathrm{BOD}_{5}=60 \mathrm{~g} /$ (resident $\cdot$ day)

total suspended solids $=55 \mathrm{~g} /($ resident $\cdot$ day $)$

the total nitrogen $=12 \mathrm{~g} /$ (resident $\cdot$ day)

general phosphorus $=2 \mathrm{~g} /($ resident $\cdot$ day $)$

\section{Domestic sewage treatment plant}

Separate loads of pollutants in waste water discharged to:

- water is not susceptible to eutrophication or ground $\mathrm{BOD}_{5}=6 \mathrm{~g} /$ (resident $\cdot$ day) total suspended solids $=7.5 \mathrm{~g} /($ resident $\cdot$ day $)$ - water susceptible to eutrophication $\mathrm{BOD}_{5}=3 \mathrm{~g} /($ resident $\cdot$ day $)$ total suspended solids $=6 \mathrm{~g} /$ (resident $\cdot$ day) the total nitrogen $=2.25 \div 3 \mathrm{~g} /($ resident $\cdot$ day $)$ general phosphorus $=0.225 \mathrm{~g} /($ resident $\cdot$ day)

\section{Treated wastewater discharged into the receiver (water or land)}

Fig. 1. The output data for design of selection of domestic treatment plants for sewage drained from buildings [2]

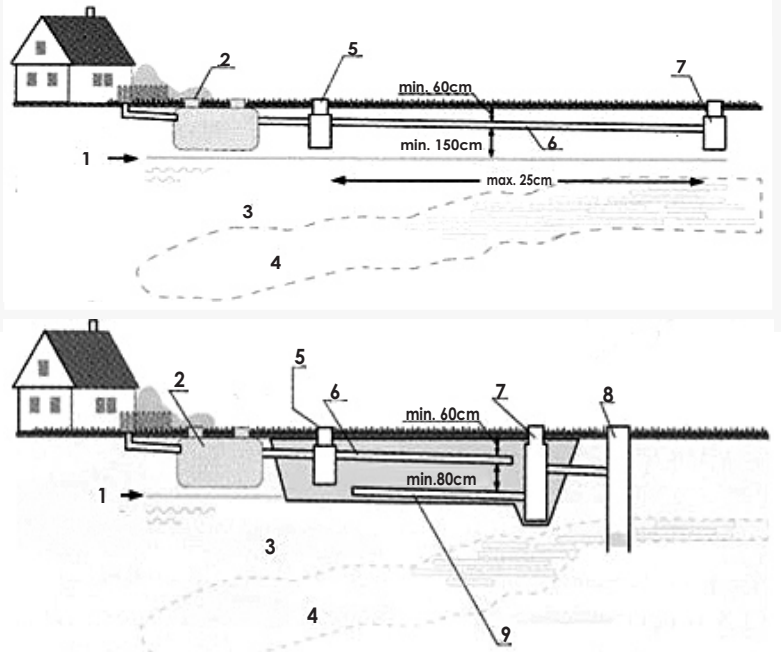

Fig. 2. Scheme of domestic sewage treatment plant [5]:

a) with drainage, b) with sand filter:

1 - max annual groundwater level, 2 - septic tank, 3 - permeable soil 4 - hardly permeable soil, 5 - sump distribution, 6 - drainage, 7 - manhole collector , 8 - absorptive well, 9 - drainage collector 
The advantages of that solution are as follows: simple structure, low purchase costs and high resistance to uneven inflow of sewage. Yet another solution may be a plant-based treatment plant, which is based on a soil and root filter (Fig. 3a). A complex plant compound, organic foundation and high diversity of microorganism species are the factors decisive as regards the effectiveness of sewage treatment. It is a frequent practice to use the common reed, the water bulrush or the basket willow in the filters. Such a solution (soil- and plantbased treatment plants) is regarded as artificial marsh ecosystems. It is also possible to treat sewage by means of treatment plants with a biological deposit (Fig. 3b), which fills a tank made most often of plastics, which have a developed biological membrane composed of groups of microorganisms participating in the process of sewage treatment (bacteria decompose the contamination in the sewage). On the other hand, the microorganisms found in a treatment plant with active sediment (Fig. 3c) are responsible for the decomposition of impurities in sewage (they do not settle on the surface, but float in the active sediment chamber - a reactive chamber). Constant air supply is necessary for such a treatment plant to operate properly [5].
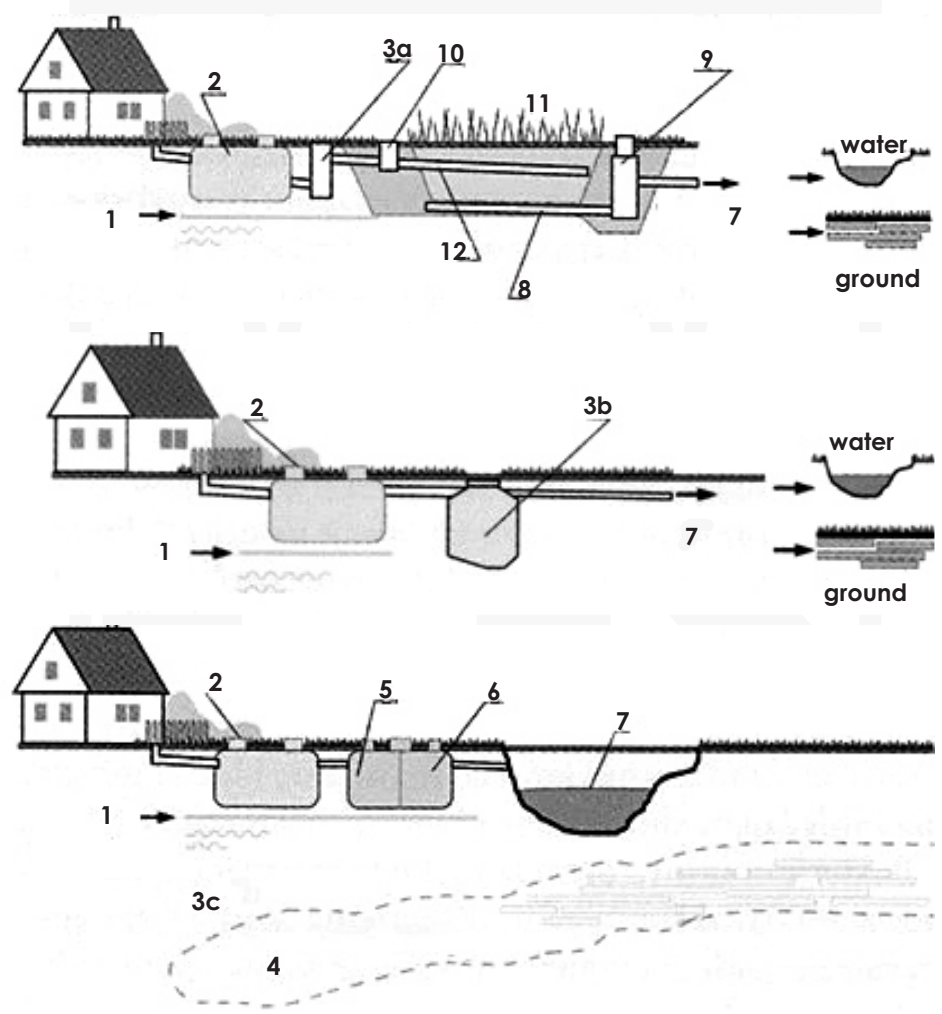

Fig. 3. Scheme of domestic sewage treatment plant [5]:

a) filter soil-plant, b) with a biological fluid deposit, c) with activated sludge,

1 - max. annual groundwater level, 2 - primary settling tank, $3 a$ - pumping station,

$3 \mathrm{~b}$ - biological chamber, $3 \mathrm{c}$ - permeable soil, 4 - hardly permeable soil, 5 - activated sludge chamber,

6 - secondary sedimentation tank, 7 - the receiver, 8 - drainage collector,

9 - collective well, 10 - well switchboards, 11 - reed, 12 - drainage 
The following are to be taken into account when selecting the best option of a domestic sewage treatment plant (the list is not exhaustive) [2]:

- soil and water conditions, including the ground water level,

- characteristics of a potential sewage receiver,

- level of contamination of the sewage receiver in relation to various contamination indicators,

- costs connected with the construction and operation of the treatment plant,

- operational reliability (related to the acquisition of sewage quality meeting the requisites of a permit under Water Law Act).

\subsection{Non-effluent tank (septic tank)}

In Poland, non-effluent tanks (septic tanks) are widely used and are still thought to be the most popular way of carrying sewage away from detached houses (Fig. 4). A non-effluent sewage system is a temporary solution when the construction of residential facilities is ahead of that of sewage management network. The solution consists in the accumulation of sewage in tight tanks the construction of which should guarantee complete tightness, preventing sewage from leaking into the ground. A septic tank should be constructed in such a way that it allows for inspections of the inside and the maintenance of good ventilation within [6].

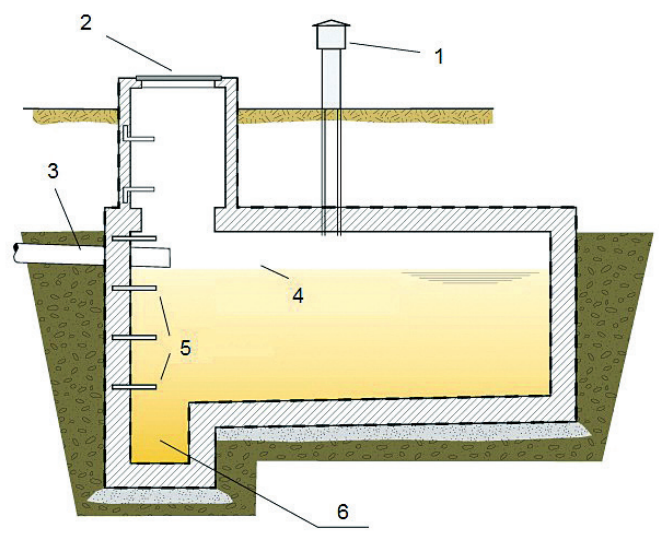

Fig. 4. Structure diagram of a septic tank [8]:

1 - exhaust pipe, 2 - cast iron manhole, 3 - bringing sewage, 4 - maximum level of sewage, 5 - degrees manhole, 6 - well of a collective

For years, septic tanks have been emptied with septic tankers, an example prototype of such vehicles is shown in Fig. 5a. Contemporarily, the disposal of sewage is carried out with tankers to a sewage storage station (Fig. 5b) located within the treatment plant. Emptying the tank is often cumbersome for the surroundings due to noise and odour [5].

They should be entirely tight, insulated both on the inside and outside [6, 7]. A septic tank should be equipped with alarm devices that inform about crossing the upper limit of sewage level (i.e. $3 / 4$ of the maximum capacity). Studies show that septic tanks are frequently 
leaky. They are sometimes made leaky on purpose in order to reduce the amount of sewage disposed. The tightness of a tank may be checked e.g. with the balance method [5]. The capacity of a tank depends on the number of residents in the house, unit amount of sewage disposed and the time of keeping the sewage in the tank [6]. The septic tank is mainly used in rural areas with scattered buildings [5].
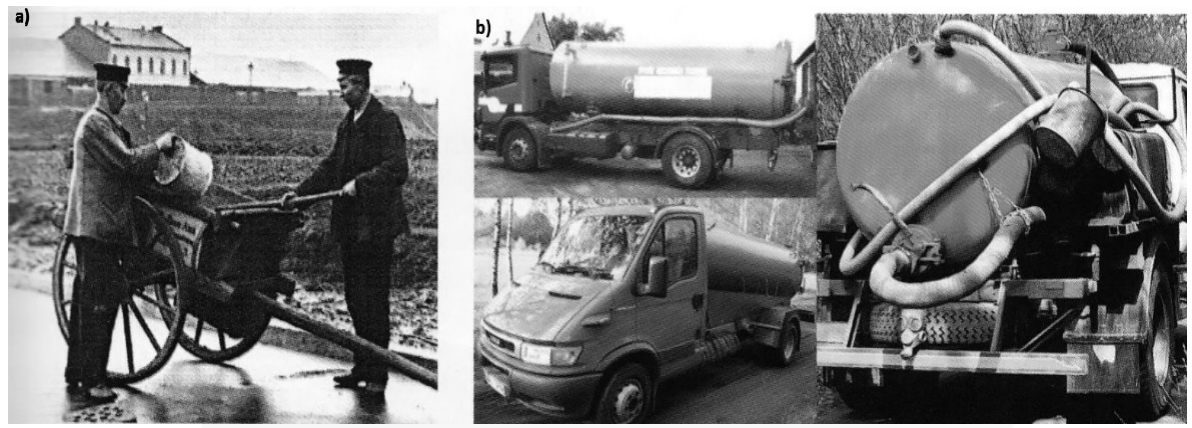

Fig. 5. Examples of septic tankers [5]:

a) the prototype of septic tankers, b) current solutions

Septic tanks may be made of concrete, brick, reinforced concrete or plastics (Fig. 6).

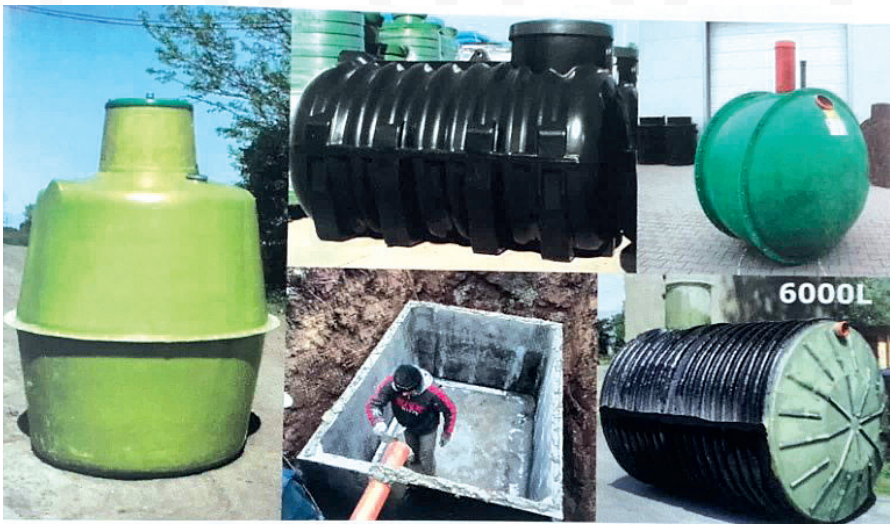

Fig. 6. Example of septic tanks [5]

\section{Comparative analysis of selected solutions}

To see the positive and negative aspects of both the domestic sewage treatment plant and the septic tank, the advantages and disadvantages of those solutions have been compared, which is shown in Table 1.

The septic tank has been a traditional solution used for many years, while the home sewage treatment plant is a modern, eco-friendly solution, which is gaining popularity. Both the septic tank 
and the home sewage treatment plant may be characterised by e.g. simple installation, tightness, resistance to mechanical damage and crushing, odour- and noise-related nuisance when the deposit is pumped out and the need for supervision and monitoring. The basic difference between those two solutions is the emptying and disposal interval, investment costs and operating costs.

Table 1. Comparison of the advantages and disadvantages of the domestic sewage drainage system

\begin{tabular}{|c|c|c|}
\hline & Domestic sewage treatment plant & Non-effluent tank (septic tank) \\
\hline Advantages & 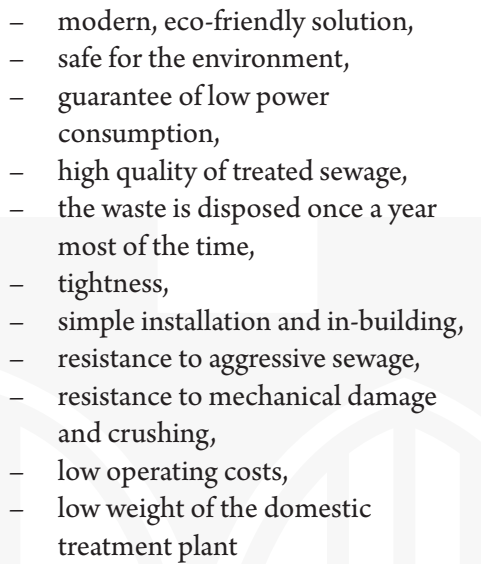 & 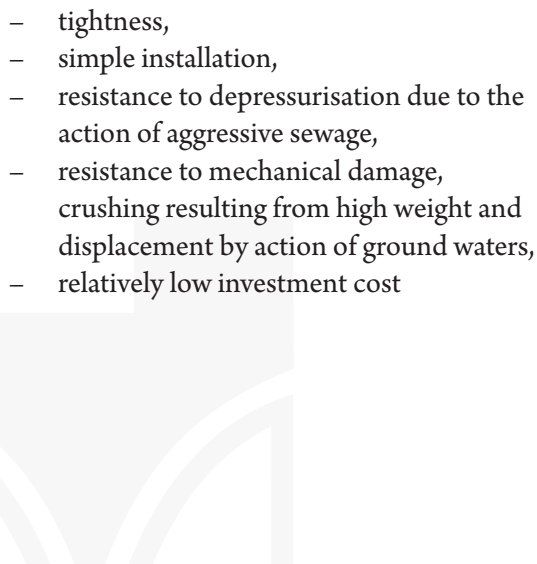 \\
\hline Disadvantages & 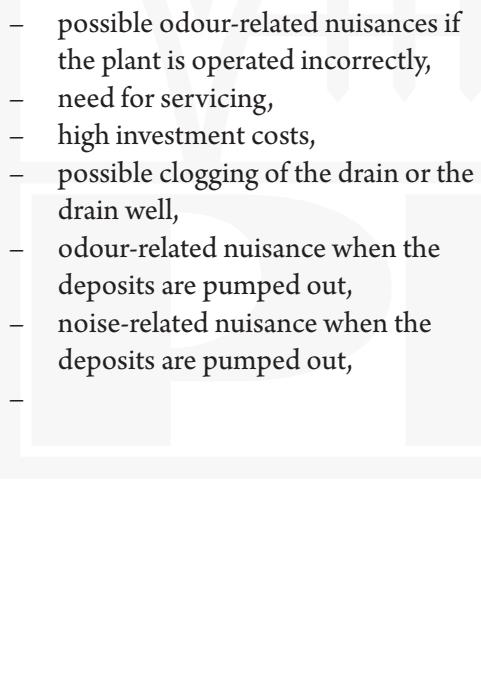 & 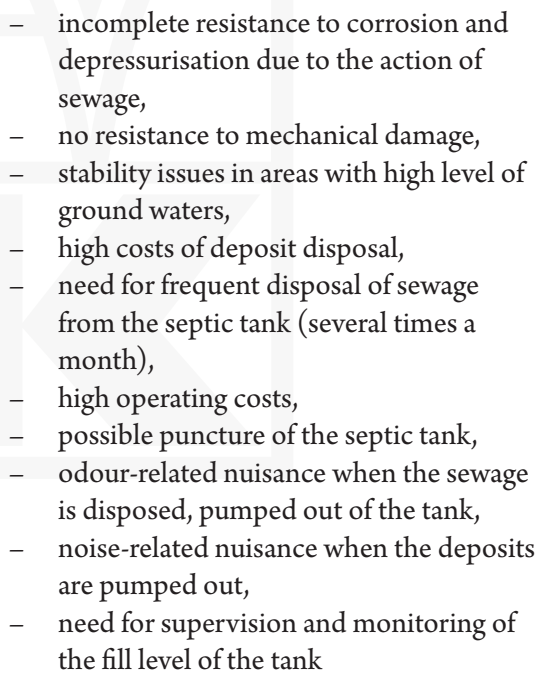 \\
\hline
\end{tabular}

To see the level of the required financial outlay, the investment and operating costs of the two discussed solutions - domestic sewage treatment plant and the septic tank - have been compared. The assumptions made for the purpose of investment and operating cost calculation:

- the devices were made by the same producer,

- the household consists of a 4-member family,

- all provided prices are gross prices, 
- $2.4 \mathrm{~m}^{3} /$ resident/month - average standard of water consumption per resident whose flat is connected to a septic tank in an area without a sewage management system and whose flat is equipped with a water supply system, toilet, bathroom, local hot water source (coal-fired water heater, gas water heater - gas from bottle, electric water heater or a boiler) [9],

- $22.95 \mathrm{PLN} / \mathrm{m}^{3}$, disposal of sewage from the septic tank with a septic tanker carried out by the ZWIK Sp. z o.o. company in Racibórz according to the price list for liquid waste disposal (applies to the Jelcz SCK vehicle with the capacity of $4 \mathrm{~m}^{3}$ ) [10],

- the number of disposals from the domestic sewage treatment plant - 1 time a year,

- the number of disposals from the non-effluent tank (septic tank) - 3 times a month,

- the investment costs of the septic tank and the domestic sewage treatment plant should be extended with the cost of the pipeline (to connect the building with the system).

The comparison of the investment and operating costs of the domestic sewage drainage systems are illustrated in Table 2 .

Table 2. Comparison of the investment and operating costs of domestic sewage drainage systems

\begin{tabular}{|c|c|c|c|}
\hline \multicolumn{2}{|c|}{ Solution } & $\begin{array}{l}\text { 2-chamber domestic sewage } \\
\text { treatment plant with subsurface } \\
\text { leaching system }\end{array}$ & $\begin{array}{l}\text { Non-effluent tank } \\
\text { (septic tank) }\end{array}$ \\
\hline \multicolumn{2}{|c|}{ Investment costs* ${ }^{*}$ PLN } & $11,600.00$ & $5,200.00$ \\
\hline \multirow{2}{*}{$\begin{array}{c}\text { Operating costs }{ }^{* *} \\
\text { PLN }\end{array}$} & per month ${ }^{* * *}$ & 25.98 & 275.40 \\
\hline & per year*** & 311.80 & $3,304.80$ \\
\hline
\end{tabular}

* investment cost of the non-effluent tank (septic tank) includes the cost of a 4,000-litre tank, installation of the system and transport in the entire country (free of charge),

** investment cost of the domestic sewage treatment plant with a subsurface leaching system includes a 4000-

litre treatment plant, a drainage system $(60 \mathrm{mb})$, installation, transport in the entire country (free of charge), washed gravel (15 tonnes) and sand-gravel mix.

*** includes the costs of operation, servicing and disposal and the cost of biopreparations.

The conducted investment cost analysis shows that it is cheaper to use a septic tank. However, from the point of view of operating costs, it is more beneficial to use the domestic sewage treatment plant with a subsurface leaching system.

Choosing the domestic sewage treatment plant over the septic tank requires that the investor pays PLN 6400 more in the beginning. The decision to use the domestic sewage treatment plant translates into monthly savings of PLN 249.42 and yearly savings of PLN 2993.00 (operating costs). Using this solution (the domestic sewage treatment plant) guarantees the savings at the level of $90.56 \%$ as for the operating costs. The septic tank is 2.2 times smaller than the domestic sewage treatment plant. When selecting the solution, it is also important to look at the fact that the investment costs of domestic sewage treatment plants are often refunded by the city council to some extent and that there is a possibility to use special preferential bank loans, loans or subsidies, e.g. from the National Fund for Environmental Protection and Water Management or a Voivodeship fund for Environmental Protection and Water Management. 
Financial support for the completion of the investment results in the fact that domestic sewage treatment plants are frequently more appealing to potential users.

\section{Conclusions}

Domestic sewage treatment plants and non-effluent tanks (septic tanks) have their proponents as well as opponents. Modern trends in the market attract attention with technical innovations. The solutions that are eco-friendly guarantee both safety and practicality through the installation of sewage management systems in households, which fulfil the basic needs and allows for a higher standard of living. Advantages and disadvantages are inherent for every solution. Nevertheless, the domestic sewage treatment plant seems to have more advantages. Based on the conducted analysis, it might be claimed that the best solution in terms of economy is the domestic sewage treatment plant, which requires higher investment outlay, but at the same time is less costly when it comes to operation.

The issue of whether to use the domestic sewage treatment plant of the septic tank is of essence from the point of view of environmental protection. To choose the best option is not easy. The presented analysis of advantages/disadvantages and investment and operating costs may perhaps facilitate the decision-making process.

\section{References}

[1] Łomotowski J., Szpindor A., Nowoczesne systemy oczyszczania ścieków, Arkady, Warszawa 1999.

[2] Heidrich Z., Wodociagi i kanalizacja - kanalizacja, WSiP, Warszawa 1999.

[3] Kalenik M., Zaopatrzenie w wodę i odprowadzanie ścieków, Wydawnictwo SGGW, Warszawa 2009.

[4] www.srodowisko.pl/artykuly/przydomowe-oczyszczalnie-sciekow-zasady-dzialaniaoplacalnosc--59671-6\#_(access: 27.04.2016).

[5] Królikowska J., Królikowski A., Żaba T., Kanalizacja - podstawy projektowania, wykonywania i eksploatacji, Politechnika Krakowska, Kraków 2015.

[6] Heidrich Z., Stanko G., Leksykon przydomowych oczyszczalni ścieków, Wydawnictwo Seidel-Przywecki Sp. z o.o., Warszawa 2007.

[7] Heidrich Z., Tabernacki J., Sikorski M., Wiejskie oczyszczalnie ścieków, Arkady, Warszawa 1984.

[8] http://archon.pl/szambo-czy-przydomowa-oczyszczalnia-sciekow-art-541 (access: 06.05.2016).

[9] Rozporządzenie Ministra Infrastruktury z dnia 14 stycznia 2002 r. w sprawie określenia przeciętnych norm zużycia wody.

[10] zwik-rac.com.pl (access: 27.04.2016). 


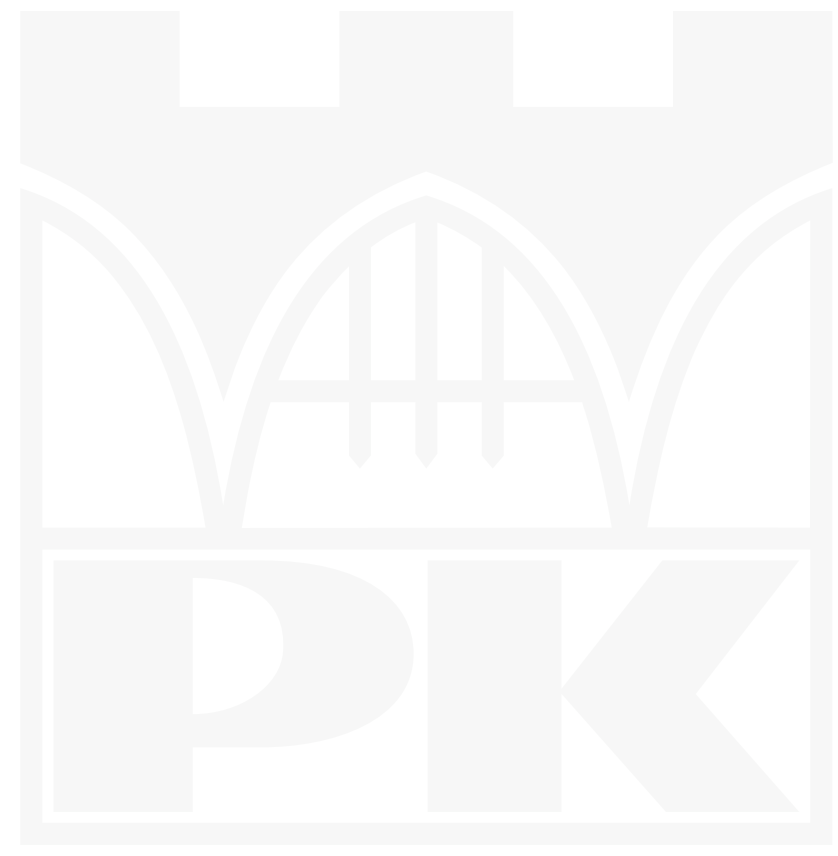

